\title{
FAMILY FIRMS WITH NEW LEADERS IN THE GLOBAL MARKET - A POTENTIAL SUCCESS STORY?*
}

\author{
Ticián BARANYAI - Miklós KOZMA \\ (Received: 28 May 2019; revision received: 23 October 2019; \\ accepted: 2 November 2019)
}

\begin{abstract}
The focus of our research is the internationalisation of the small-medium size family firms in Hungary, with particular attention to the effect of generational change on internationalisation. Our examination is based on interviews with the current management of six family firms from different industries. We had two research propositions: First, we analysed if and how successors in the family businesses were more open to the internationalisation of the company. Our results provide insights reflecting that the predecessors are usually quite open, and successors are not always as open when they assume control over the company, unlike the existing internationalisation patterns of family firms would suggest. Potential explanations reveal related characteristics of the Central-Eastern European (CEE) region. Secondly, in terms of how and why the leadership style and approach of the predecessors affect the internationalisation of family firms, our findings from different cases vary. The historical and cultural background of the family firms' founders and early-generation successors exert notable influence on the internationalisation process, while the role of predecessors' personal characteristics may not be as strong a driver of internationalisation as previously suggested. The management implications of our findings suggest that the Hungarian family firms show regional patterns in terms of their internationalisation, and generic approaches to generational change and succession may not explain the process as much as extant literature on international family business suggests.
\end{abstract}

Keywords: family business, internationalisation, succession, generational change, Central-Eastern Europe, case studies, Hungary

JEL classification indices: F23, L26, M16

* The authors are grateful for the comments and suggestions of the two anonymous referees on a previous version of the article.

Ticián Baranyai was a BA student of Corvinus University of Budapest at the time of writing the original version of the article. E-mail: tician.baranyai@gmail.com

Miklós Kozma, corresponding author. Associate Professor at the Institute of Business Economics, Corvinus University of Budapest. E-mail: miklos.kozma@uni-corvinus.hu 


\section{INTRODUCTION}

The economic role of family businesses is substantial globally. According to the Family Firm Institute (2017), 50-80\% of jobs are provided by family businesses worldwide, two-thirds of all companies are family businesses and they generate $70-90 \%$ of the annual global GDP. Regarding the last measure, Zellweger (2017) quotes a more moderate estimate ranging between $40-70 \%$. With regards to Hungary, the prestigious economic weekly, HVG published the survey results in 2016 according to which half of the jobs in the country are provided by family businesses with an overall GDP contribution of over $50 \%$.

Family businesses attract significant scholarly interest as well. Kontinen Ojala (2010a) highlighted that succession is a key topic of publications as it is seen pertinent to family firms' sustainability. More recently, internationalisation rose on the publication agenda (De Massis et al. 2018), while many aspects of this research field remain unexplored. Few research publications have addressed the topic of our research: the effects of generational change on the internationalisation of family businesses. The subject is particularly pertinent in Hungary, as a significant proportion of family businesses were established in the early 1990's, with their founders reaching retirement age and looking for appropriate succession options now (Noszkay 2017).

In this article, in Section 2 we show the theoretical background of the topic, including the approaches to family business, and the complex issues of generational change. The role of the predecessor and the successor is explained in more details. The general approaches to internationalisation of firms are also highlighted, with particular attention to the seminal Uppsala model, widely claimed to be a relevant framework for explaining the internationalisation of family businesses. In Section 3 , the empirical focus of our research is introduced, discussed together with our methodology. Our results are explained in Section 4, followed by a discussion in Section 5 and conclusion with theoretical and management implications as well as suggestions for future research in Section 6.

\section{THEORETICAL BACKGROUND}

The background of our examination is based on two major areas of research: family business with particular attention to succession, and the internationalisation of companies. In the following sections we briefly summarise the most fundamental empirical results pertinent to our subject. 


\subsection{Family business as a concept for scholarly research}

Defining family business is a fundamental challenge for the scholars in the field (Handler 1989). A critical concept underlying all definitions is how family as an institution is understood (Astrachan - Shanker 2003; Sharma 2004; Zellweger 2017). The phenomenon of family is often left undefined (Astrachan et al. 2002), partly explained by the fact that it is a gradually changing concept due to emerging trends in modern societies (e.g. most marriages end up with divorce). Consequently, while attempts of defining family business were numerous over the last decades (e.g. Sharma 2004; Zellweger 2017), approaches vary greatly and are sometimes contradictory (Wang 2010; Csák Farkas 2012; Cano-Rubio et al. 2017).

In light of the above, the European Commission (EC) proposed a definition focused on two key components (European Commission 2009): family firms have at least one family member in the management, and shareholder decisions are greatly influenced by family members. The actual interpretation of significant family ownership usually varies across different scholars (Al-Dubai 2014; Noszkay 2017), but the EC suggests a $25 \%$ minimum for public corporations and $50 \%$ minimum ownership for private companies. By contrast, another approach to family business was applied by Zellweger, which we will use for the purposes of our current research as well: "family firms are businesses with dominant family control and a vision to maintain family control across generations" (Zellweger 2017: 22.). This definition stems from the seminal work of Chua et al. (1999), who proposed a definition with two dimensions: a vision held for the firm by a family, and their intentions to shape and pursue that vision.

Another critical point of interpretation is what family control means. Family members may play the roles of owners, managers or both in the company (Chua et al. 1999; Wang 2010). Astrachan et al. (2002) introduced the F-PEC scale ${ }^{1}$ for the purpose of comparing family control across organisations and how much this control actually affects business performance. According to their model, family influence stems from its role in ownership, control over decisions and actual management. A similar model of Zellweger (2017) differentiates five dimensions of family influence as follows:

1. extent of family control,

2. complexity of family control,

3. the orientation of business operations,

4. the philosophy and goals of the family owner, and

5. the history of family control.

The F-PEC scale is a valid instrument of family influence, it comprises three subscales: power, experience, and culture. 
Zellweger recommends the model to be used to clarify the role of the family within the firm, and also help understand the heterogeneity of family businesses and its effect on problems related to family influence. Another model created by Anderson et al. (2005) differentiates family firms where the family rejects involvement in the business decisions, or their role is only informal, and in contrast, where the family has strategic control and an intention to succeed the management of the firm across generations. Most importantly for our research purposes, they identify family businesses as entities where there is cooperation between family members across generations.

\subsection{Succession as a critical issue in family business}

Diverse as family businesses may be, there is one certain challenge they all confront over time: succession, i.e. the transfer of ownership, control or management rights to a younger generation (Miller et al. 2003). Succession is a critical step in each family business leader's life, as it fundamentally affects the sustainability of the business (Miller et al. 2003; Csák Farkas 2012; Goto 2014). Succession, naturally, has an impact on the internationalisation of family firms due to its effect on the continuation of business (Kontinen-Ojala 2012). Miller et al. (2003) differentiates three types of succession: conservative (no major change in business strategy), rebellious (radical change occurs) and wavering (a mix of the previous two, as the successor has his or her own vision but little understanding of its implementation).

Succession and its planning are a forceful topic of scholarly research. Michel Kammerlander (2015) identified four major tasks of succession planning in family businesses: (1) creating awareness of succession for the predecessor, (2) defining the objectives, principles and agenda of the process, (3) selecting the successor based on a number of criteria, and (4) training plan for the successor. As these tasks suggest already, the successor may not be a manager from the family; all the more, succession within the family has lost its popularity recently around the world (Zellweger 2017). The complex process of succession is influenced by not only the key stakeholders, but also the competitive position of the firm (Noszkay 2017), as well as the technical complexity and timing uncertainties of the process (Zellweger 2017). Contingencies in the external environment, the availability of scarce resources, as well as the interrelated family and business systems are also understood to exert influence on succession (Devins - Jones 2016).

A key stakeholder in succession is the predecessor, who is in charge of the company, hence his or her influence on its performance, as well as its culture and values (Sharma 2004). Predecessors decide when succession is realised (Csák 
Farkas 2012). Ziniel - Voithofer (2016) calculated an average age of 54 years when predecessors typically organised the actual succession in Austrian family firms. Similarly, Bálint (2006) concluded in his analysis of a Hungarian sample that if succession was planned only at an older age, predecessors might not have enough time to prepare the successor. The outcome of the process was largely contingent upon the leadership style of the predecessor, and their role in succession. Regarding leadership styles, Sorenson (2000) differentiated participative, autocratic, laissez-faire, expert, and referent types. Overall, the role of the predecessor in succession is a well-researched topic in the literature.

In terms of the retirement styles of predecessors, Sonnenfeld (1988) typified the cases by creating four categories. Monarchs stay in power until they have to leave. Generals are also unwilling to leave, but they also have a plan that once they leave, they may come back to control the firm if they are needed. By contrast, ambassadors are open to leave their position, and will help the successor with advice. Finally, governors stay in power until a definite deadline, and then look for other opportunities outside the company. Poza (2007) and Csák Farkas (2012) refer to two additional types, the inventors, who decide to leave the firm and start another company, but remain available if needed, and the tsars of succession, who drive the process with vision and initiative throughout. Bálint (2006) also underlined the importance of the experience and personal character of the predecessor, as these usually shape his/her expectations regarding succession. A founder, who has vast experience and is relentlessly willing to take risks, may approach challenges, including that of succession, much more openly.

As the potential roles of the predecessors suggest, they are often hesitant to leave or even to plan their departure. This is understood to be the consequence of the phenomenon that their extant successes and strong emotional links to the company urge them to protect what the company has achieved already, instead of taking risks for the future, including finding an appropriate successor (Zellweger 2017).

In Hungary, and for that matter also in the Central-Eastern European (CEE) region, there is little historical precedent of managing the succession within family businesses, due to major ruptures in any intended continuation of family control in businesses. More often than otherwise, the ownership and control of original family businesses were misappropriated through various legal or illegal means, especially in the troublesome periods of the $20^{\text {th }}$ century. This lack of existing patterns of continuation and organic succession makes the challenge of forthcoming generational change even more daunting (Noszkay 2017).

Another key stakeholder in the process is naturally the potential successor. Compared to the predecessor, in general, they are less connected to the firm emotionally, more open to change business by rational reasons, they are resourceful 
in terms of energy and ideas, and they are more forward-looking in their approach (Zellweger 2017). With regards to their motivation to get involved in the family business, they may be willing to strengthen the family identity and its reputation, see the leadership role as attractive, and feel the urge to outperform their predecessors. Sometimes, of course, they might as well try to avoid causing disappointment to their family (Chalus - Sauvannet et al. 2016).

There are a number of reasons to be careful when selecting a successor. A preliminary question is whether there exists a potential successor willing to take charge of the company. If such a person exists, he/she may not have the personality that fits the strategic profile of the company. All the more, the successor is expected to be in good relationship with other family members, able to command respect, and he or she needs to respond to different types of demand from the business (Poza 2017; Csák Farkas 2012). Further complexity is involved if there are more potential successors within the family. Some of them may stay away from rivalry and conflicts or think of themselves as inappropriate for the job.

\subsection{Internationalisation of firms}

Internationalisation is a multi-fold concept in the literature. Antalóczy - Sass (2011) pointed out that the size of the company is a strong differentiator, as the objectives and fundamental drivers of internationalisation are perceived to be much different for small firms than for even medium ones. In the present environment, especially within the EU, internationalisation has become a ubiquitous process, regardless of its drivers or the size of the companies. A widely used definition of internationalisation depicts the phenomenon as the process of a company's participation in international operations (Welch - Luostarinen 1988; Antalóczy - Sass 2011). Éltetó - Udvari (2018) pointed out that internationalisation may manifest itself in various forms from casual export to continuous intercompany cooperation, and it can even be reversed over time. Melin (1992) claimed internationalisation as an overarching strategic process, while probably the most general definition is focused on international transactions.

In terms of the theoretical approaches of internationalisation, Éltető - Udvari (2018) differentiated between three types: staged, network-based and international corporate approaches. Antalóczy - Sass (2011) denoted a different categorization: staged internationalisation, the economics approach to internationalisation and the "born globals" approach. With a focus on small and medium sized enterprises, Onkelinx - Sleuwaegen (2008) differentiated four groups of internationalisation models: the staged models, the born globals theory, the international network models and the holistic approaches. The variety of approaches and their 
categorisation reflects the diversity of the topic and the need for continuous theoretical advancement in order to capture some of the apparent complexity shown by the basic phenomenon of practical nature.

The Uppsala model (Johanson - Vahlne 1977, 2009, 2013) is a seminal version of the staged approaches to internationalisation, and the most widely used of all internationalisation theories. It suggests that internationalisation is a gradual process that requires increasing levels of commitment, through which the company acquires market specific knowledge from experience (Incze 2010). Consequently, firms tend to choose exporting first as it requires lower levels of local market knowledge, and opt for activities requiring stronger integration in later stages (Bartha - Gubik 2016). Antalóczy - Sass (2011) emphasised the role of the decision process as management learns more of internationalisation due to increasing availability of market knowledge and information. Psychological distance is understood to influence market selection significantly, hence companies' choice of neighbouring countries first and moving to geographically and culturally more distant countries later (Éltető - Udvari 2018). Small and medium sized enterprises are generally sensitive to such distances (Mikesi 2013), while actual firm strategies show remarkable diversity in terms of the process of internationalisation (Incze 2010).

Since its inception, the Uppsala-model has been widely used, and also criticised by scholars of the field, while the model was updated a couple of times. As a fundamental point of critical comments, Santangelo - Meyer (2017) highlighted the overly general nature of the model. Nevertheless, based on a Polish sample, Daszkiewicz - Wach (2014) claimed that family firms typically follow the process described by the staged model as they first move to neighbouring countries due to perceptions of psychic distance. By contrast, Graves - Thomas (2008) noted the relevance of the born globals theory to family firms. Antalóczy - Éltető (2002), in their analysis of Hungarian firms, concluded that only a portion of small and medium enterprises follow the staged pattern, contingent on their involvement in different markets and industries. In their major update to the model, Johanson - Vahlne (2009) acknowledged the importance of networks in the internationalisation of companies, partly due to the consistent elaboration of the topic by Coviello - Munro (1994, 1995, 1997 and others). They also noted a diminishing influence of psychic distance on foreign market entry, which may affect the decision maker more than the firms themselves.

Globalisation is understood to bring forward an alternative, network-based model of internationalisation. As the exchange of information and goods across borders became facilitated by the increased availability and relatively low cost of information technology, some firms opted to enter markets outside their immediate neighbourhood. Incze (2010) noted that the network models focus on firms 
operating in formal and informal networks, driving analytical focus of research from the characteristics of companies to those of the business environment and context. Antalóczy - Sass (2011), in their interpretation of the model, highlighted that gradual internationalisation may be realised through financial, commercial and technological interactions within members of the networks. Such members can range from customers, suppliers, competitors, friends, and most notably for us, the family (Coviello - Munro 1997).

While interfirm relationships within the network naturally influence strategic decisions beyond the scope of internationalisation, it is fundamental for our analysis that they may provide access to essential resources that support foreign market entry (Cerrato et al. 2016). Such advantages of network membership may offset some of the disadvantages small firms sustain in international competition (Zou - Stan 1998; Cerrato et al. 2016), like unfavourable scale economies, as well as limited access to financing and qualified human resources. Partly due to its relevance to global value chains, the network approach to internationalisation gained increasing attention over the last decades (Éltető - Udvari 2018). Critics of the approach pointed out that it is more suitable to analyse the external factors of internationalisation than the process itself(Incze 2010; Antalóczy - Sass 2011).

The turn of the millennium brought to life an increasing number of born global companies that utilise a wide range of existing experience and knowledge in order to internationalise rapidly. Most of these firms operate in knowledge-intensive industries and reject classical, staged patterns of internationalisation (Antalóczy - Éltető 2002). They learn from each other due to the increasing availability of knowledge in the internet age (Antalóczy - Sass 2011). They are founded not just to survive, but to grow significantly and rapidly (Mikesy 2013). Born globals are typically small to medium size ventures that build their competitiveness around unique knowledge in a market segment they may become a defining player of (Antalóczy - Éltetö 2002). While the term born global has been in use since the mid-1990's, one of its key protagonists, Coviello (2015) recently called for a rethinking of the concept. She pointed out that digital technology has, only more recently, allowed truly born global firms to emerge, hence the subjects of former studies were rather "born internationals" or "born regionals".

Apart from the above, a number of alternative approaches to internationalisation were conceived in the last decade, most notably the holistic, the economics based and the innovation approaches. The holistic approach is fundamentally focused on small and medium sized firms, with an increased range of dimensions to internationalisation (Incze 2010), while the economics based approach is an extension of Dunning's OLI paradigm (Antalóczy - Sass 2011). The innovation approach puts emphasis on psychic distance and links to the staged approach but interprets internationalisation as an innovation process. The actual steps of 
this innovation process, however, are yet to be identified with consensus in the literature (Éltető -Udvari 2018). Nevertheless, with regards to our present article, we rely on more established theories of internationalisation as a framework of empirical analysis.

\subsection{Internationalisation of family businesses}

Internationalisation is a pivotal theoretical field in international business, but its specific aspects related to family businesses is a topic which is relatively new and unexplored (Kontinen - Ojala 2010b; Fang et al. 2018). Kontinen - Ojala (2010a) argued that the role of family business in the global economy is gaining strength, while an increasing portion of family firms are under pressure to internationalise, due to competitive forces. Daszkiewicz - Wach (2014) highlighted the relevance of this research area, particularly in the CEE region. This is in line with the findings from the meta-analysis of the field by Arregle et al. (2017), who concluded that the relationship between family firms and internationalisation varies across countries and is largely dependent on the local institutions, both formal and informal. There are some general phenomena but the specific examination of the topic in different regions can reveal local idiosyncratic patterns. Meanwhile, Pukall - Calabro (2014) concluded that the assessment of family influences on internationalisation is heterogeneous, and there appears tu be a lack of a common understanding of the phenomenon.

The theoretical background of the internationalisation of family businesses builds on classical internationalisation. Kontinen - Ojala (2012) pointed out that some of the family businesses are born globals, while the more typical family firm goes international following a staged process (Daszkiewicz - Wach 2014). These two groups of family firms show distinct characteristics along a number of major aspects. Traditional family firms usually have their ownership rights spread across family members, and their management shows signs of stewardship, as opposed to the usual case of "born globals". Traditional family firms use international fairs and trade shows to look for international opportunities, while born globals have existing, strong network relationships right from their inception. Psychic distance is an issue for traditional family firms, and they also tend to focus on business with primary partners in a less entrepreneurial fashion, while born globals consider psychic distance less of a problem and pitch for new contacts in more competitive markets. Finally, traditional family firms invest less into research and development and focus their efforts on sales in domestic and foreign markets. By contrast, born global companies typically build their business around technology intensive products that require intensive investment into 
innovation, use research partnerships, and are generally ambitious and agile in terms of product development.

The recent context of the internationalisation of family businesses has been profoundly shaped by the impact of the global economic crisis since 2008, which put pressure also on firms in the CEE region. While most of the small-to-medium size firms in the overall export-driven Hungarian economy were not involved in exports directly, the ripple-down effects of the crisis hit them significantly. At the same time, their potential foreign market entry was supported institutionally by domestic and international organisations, most notably, the EU (Cernat et al. 2014). Notwithstanding the effects of the global economic crisis, the process of internationalisation of family firms shows idiosyncratic patterns that substantiate an emerging subject to scholarly research (De Massis et al. 2018). As a common starting point for researchers in the field, family firms are generally assumed to be less likely and less willing to operate outside their domestic market. This was confirmed by the meta-analysis of Arregle et al. (2017) as well.

The reasons for family firms' general hesitance to entering foreign markets vary greatly. According to the literature a range of factors are assumed to make a related impact. First, family firms face the usual challenges of small-to-medium size firms, like the lack of market information and ability to speak foreign languages (Éltető - Udvari 2018), as well as insufficient planning and limited access to financing (Mikesy 2013). Arregle et al. (2017) approached this phenomenon as multinationality in geographic scope, which creates managerial challenges that family firms try to avoid. Secondly, there are specific restraining factors as well. Maintaining the socio-emotional wealth (SEW) is a characteristically strong motive for family firms' management, and this usually hinders their decisions to internationalise (Fang et al. 2018). Also, family firms are less likely to involve external expertise, which is often needed for international expansion, due to the fear of loss of control (Kontinen - Ojala 2010a), particularly if the emotionally biased first generation is still in charge of the business. Other sources of limitations may be the over-commitment to the identity of the family firm, strong personal relationships with key stakeholders, or simply the management's determination to find a successor within the family (De Massis et al. 2018).

The challenge of generational change adds to the complexity of the above problem. Early results of scholarly analysis showed that internationalisation may speed up as a result of succession within the family (Graves - Thomas 2008; Kontinen - Ojala 2010a). Fang et al. (2018) explained this phenomenon with the successor's less intensive emotional links to the firm, or their tendency to pursue direct business interests rather than prioritising the maintenance of SEW. On the other hand, research also revealed the occasional negative effects of new genera- 
tion management to the international activity of family firms. Csák Farkas (2012) underlined the fact that many family firms perform best under first generation management, regardless of the level of internationalisation achieved. Shi et al. (2018) concluded that the effect of generational change on the internationalisation of family firms had been researched less than what the relevance of the issue would justify in terms of its effect on the future of the business.

\section{RESEARCH OBJECTIVES AND METHODOLOGY}

As the review of selected literature suggested, family businesses, and the key management challenge of succession are a major field of interest in scholarly research. Their internationalisation, as a critical aspect of their strategic management is gradually rising on the publication agenda. The link between the two concepts (that is the effects of generational change on the internationalisation of family firms) is an especially pertinent topic in CEE, as due to the historical background of family firms' development, both succession and internationalisation are generally difficult challenges in all these countries. Many of the family firms were established 25-30 years ago, hence generational change is naturally on their agenda. With respect to the relatively limited domestic markets, internationalisation is an unassailable factor of their strategic management that both predecessors and successors need to respond to related challenges both in the domestic market and when potentially expanding abroad.

There are very few family firms with significant size in Hungary, hence the scholarly examination of the topic is particularly relevant for the small-to-medium size family firms. Furthermore, the generic objective of most of local family firms is to maintain the family's involvement in both ownership and decisionmaking authority, hence a closer focus on succession aiming the remaining control of firm by the family is justified. There have been only a limited number of studies on the above topic in Hungary, hence an exploratory study of the relationship between succession and internationalisation of these firms is necessary to define opportunities for more bespoke future research of potential local patterns of management.

Due to the exploratory nature of our current research, we have relied on the early results of discussions with the management of selected family firms and selected our research propositions according to those issues that they claimed to be in their primary interest. Hence, no theoretical model has been applied to formulating the propositions. It is our intention to examine the topic with more formal theoretical models at a later stage. 


\subsection{Hypotheses}

Based on the above, we constructed two hypotheses that reflect our expectations regarding the potential role of the predecessor and the successor on the future international performance of small-to-medium size family businesses in Hungary.

Hypothesis \#1: The leadership style of the predecessor in the context of succession has a critical impact on the internationalisation of the firm.

As noted above, there is a range of options of how succession may be achieved within family firms (Shi et al. 2018). With regards to the style how the predecessor presides over the succession process, Bhalla - Kachaner (2015) discerned that good communication and the early involvement of the successor in the process play a defining role in the ultimate results of generational change. If the predecessor behaves, for example, as a monarch or an ambassador of succession (Sonnenfeld 1988), and whether he/she has autocratic, participative or another style of leadership (Sorenson 2000), these conditions are understood to affect succession greatly. As the development of the firm's future business influences its willingness and ability to enter foreign markets, we presume that the leadership style of the predecessor in the context of succession affects family firms' internationalisation. Shi et al. (2018), based on a Chinese sample, provided positive evidence to that argumentation. Nevertheless, the novelty of the subject calls for further analysis, particularly in the CEE context.

Hypothesis \#2: Successor-led family firms are more open to internationalisation.

As Csák Farkas (2012) pointed out, predecessors may be reluctant to internationalise, due to their over-commitment to maintain the SEW of the family firm. They tend to see the influence of involving external experts and capital as a potential loss of control over the firm. Meanwhile, successors usually pay less interest to maintain SEW but put more direct emphasis on improving the business performance of the firm, often with the intention to exceed the achievements of the predecessor (Fang et.al. 2018). Furthermore, the experience and readiness of owners and management is a crucial driver of internationalisation (Chikán - Czakó 2014). Over the last decades, the proportion of the Hungarian population with higher education qualifications and the knowledge of foreign languages have significantly increased (KSH 2010, 2017). In terms of the environmental conditions, Hungary's accession to the EU facilitated the foreign market entry of firms (Mikesy 2013), partly due to the supportive policy of the EU in terms of 
the internationalisation of small-to-medium sized firms (Cernat et al. 2014). The export intensity of the Hungarian economy is continuously increasing, despite the temporary setback during the global financial crisis, mainly targeted to countries of the EU. Hence, our presumption is that those successors are generally better prepared and able to lead their firm to internationalisation.

\subsection{Methodology and sample}

We presumed that there will be special phenomena explored due to the historical and cultural background of the CEE region. Our approach integrates the contextual setting of the cases examined in line with the recommendations of Fletcher et al. (2016), who also advised that qualitative research needs further extension regarding the contextual aspects of family business performance.

In our effort to explore the potential special regional characteristics, we chose the multiple embedded case study research methodology based on the argumentation of Yin (1994). Our decision was supported by the fact that we do exploratory research, without the direct intention to prove or falsify closely defined relationships between pre-identified variables. Our approach is more focused on understanding how and why generational change may have an effect on internationalisation with the expectation that we will explore potential variables that can be the subject of a more rigorous explanatory analysis at a later stage. De Massis - Kotlar (2014) also claimed that "an exploratory case study should be used when the aim is to understand how a phenomenon takes place" (ibid. p. 16.). Our investigation has no effect on the actual development of events at the examined firms, and the phenomenon in focus is very timely, with little, if any extant empirical results available to build our potential hypotheses upon. Incze (2010) also highlighted the relevance of the case study research methodology in case the examined phenomenon is explored dynamically as it develops over time. The narrative nature of the case studies allows the exploration of more complex, detailed relationships between fundamental concepts, uncovering potentially confidential claims or emotions, which themselves can be of significant importance in case of generational change within families, and the lure or fear of internationalisation.

In-depth interviews were chosen as the most appropriate data collection method for our research. De Massis - Kotlar (2014) proposed interviews as a "targeted, insightful and highly efficient means by which to collect rich, empirical data, especially when the phenomenon of interest is highly episodic and uncommon" (ibid. p. 19.). Babbie (2000) also explained the key strength of interviews in supporting deeper and more complete understanding of complex phenomena, like family businesses. All the more, quantitative investigations would have been 
less appropriate to explore interactions between employees and differences between their views (Cesaroni - Sentuti 2017). Another favourable feature of the interview method is that the interview questions can be adjusted to the findings that researchers learn about as the investigation progresses and add further depth or focus to the potential new findings. Finally, without an explicit budget and institutional support, the feasibility of conducting interviews was proven to be more robust compared to any potential survey type of research.

Interviews, on the other hand, have disadvantages as a research method, as well. As Babbie (2000) pointed out, the personal nature of the method limits the reliability of findings, as each conversation between two individuals is unique and may not be perfectly reproduced later. Yin (1994) also emphasised the limited generalisability of the case study methodology, hence no real statistical generalisation, rather analytical generalisation can be intended. In our research, we do not aim to generalise our findings to all family firms in Hungary or in CEE but are willing to understand the reasonable scope of future explanatory studies with more focus on generalisation.

Our initial list of potential case study companies included 10 small-to-medium sized family firms with notable level of international involvement either in their past, present or at least in their future plans. Another selection criterion was that they have reached a stage in their development that generational change in management has been or is on their agenda, so that they have some experience to share in terms of their approach to succession. Regarding the size and age of the firms we intended to select a variety of cases to our sample to allow more complete understanding of the examined phenomena. Our sample selection approach has not been random, as the potential interviewees were all either direct or indirect acquaintances of the interviewer. The internal variance of the sample is high, with regards to the industries the firms are active in and also in terms of the stage of internationalisation they are at. After the initial desktop data collection and preliminary discussions with potential interviewees, finally six companies have been selected for more thorough analysis. An overview of the companies finally selected in our sample are shown in Table 1, using code names to protect their confidentiality.

For each company in the sample, one or two interviews were conducted with either the predecessor or the successor, or both at the given family business. A single interviewer made all the interviews so that the potential inconsistency between different interviewers could be limited. The interviews were 60-90 minutes long, and all were conducted in July 2018. The discussions were recorded and systematically analysed in their transcript form to ensure a valid basis of analysis (with two exceptions where the location was too noisy for the audio recording). This analysis focused on identifying the relevant interview content 
Table 1. Companies in our research sample

\begin{tabular}{l|c|l|c|c|c}
\hline $\begin{array}{l}\text { Company code } \\
\text { name }\end{array}$ & Est. & Key scope of activity & $\begin{array}{c}\text { Nr. of } \\
\text { emp., 2017 }\end{array}$ & $\begin{array}{c}\text { Annual sales, } \\
\text { 2017 (EUR) }\end{array}$ & Interviewee \\
\hline Juliett Limited & 1970 & $\begin{array}{l}\text { Wholesale of metal } \\
\text { tools and equipment }\end{array}$ & 89 & 5413586 & Predecessor \\
\hline Sierra Limited & 1971 & $\begin{array}{l}\text { Production of } \\
\text { confections }\end{array}$ & 238 & 11142195 & Predecessor \\
\hline Kilo Limited & 1987 & $\begin{array}{l}\text { Iron, paint and } \\
\text { glassware trade }\end{array}$ & 28 & 5134931 & Successor \\
\hline Whiskey Limited & 1996 & $\begin{array}{l}\text { Distribution of dental } \\
\text { goods }\end{array}$ & 4 & 70441 & Predecessor \\
\hline Golf Limited & 2002 & Road freight services & 78 & 5453228 & Successor \\
\hline Charlie Limited & 2003 & $\begin{array}{l}\text { Real estate rental and } \\
\text { operational services }\end{array}$ & 4 & 13524 & $\begin{array}{l}\text { Predecessor } \\
\text { and successor }\end{array}$ \\
\hline
\end{tabular}

Source: Interviews and annual reports, 2017.

for the two propositions and if and how different elements of the collected information were in line with initial expectations or raised new questions. Our understanding of the issues developed gradually as we moved on from case to case. The locations of the interviews were in Western Hungarian cities and Budapest, where the company management was active.

The interviews were semi-structured, with preliminary questions defined to guide the discussion, but the interviewer let the interviewee talk as he or she considered the content relevant without strict adherence to the originally defined questions, as suggested by the methodology best practice (Cruz-Nordqvist 2012). There were 11 questions asked of predecessors and 10 questions of successors related to generational change, and if it was possible, another set of 16 questions related to the company's approach to internationalisation in a dynamic context. Succession related questions ranged from the objectives, fears, options, to roles played and interactions between family members, while questions related to internationalisation ranged from the key facts, the process, objectives to the approach of different family members, their related cooperation and future expectations.

\section{RESULTS OF THE CASE STUDIES}

In this section we reveal the analytical insights related to our research questions from each company, in the order of date of their establishment. This covers the findings of generational change and also internationalisation reflecting the logic how these topics actually appeared in the interviews. Where possible, we included verbatim extracts from the interviewees to enrich the findings with personal 
insights as they arose. The companies appear under code names to protect their identity. ${ }^{2}$ Also, quotations from the interviewees appear without their real names, using simple codes. A more structured assessment of the results in a comparative approach follows in the next section.

\subsection{Juliett Limited}

Juliett Limited was founded in 1970 by a married couple. They opened the very first "Do it Yourself" (DIY) store in Hungary. The successor, their son took over the management of the company in 1983 and started to enlarge its product portfolio. Today, their scope is quite diverse, from intelligent solar panel system implementation services to simple bags or winery tools. The third generation joined in the ownership of the company in 2004. As international activities of privatelyowned companies were very limited in the 1970's and 1980's, for the purpose of our research, the second generation (our interviewee) is interpreted as the predecessor, and the third generation of family management as the successor.

Originally, international activities were not ambitioned for the company, although there was financing available, and the management possessed fundamental skills, like languages. On the other hand, the management did not intentionally reject internationalisation, just did not give priority to such opportunities. Later on, in response to changes in the external environment provided the necessary incentives for the company to start going international. "We did cooperate with local joint ventures before, but we started export activities because of our multinational clients. They took us abroad (...) There were no language issues, as most of our suppliers were from Germany, and I speak German, many of our colleagues also speak other languages". Export activities started in 2000, mainly focused on neighbouring countries, such as Romania, Croatia, Austria and Slovenia. After Hungary's EU-accession, in 2005, the company made its first import from the Far-East.

Since that, the company de-internationalised, i.e. it started to focus on its domestic market and broadened its product portfolio. This de-internationalisation is not against local patterns in the region (Stocker 2017, 2019; Stocker - Czakó 2018). "Our current export activity is minimal, largely limited to Serbia, but without much ambition. Our strategy is not about internationalisation, I am not interested in that." While our interviewee, the current manager of the company does not see the next generation to be against the current strategy, he could not deny

2 We are, of course, fully aware that those readers of the present paper who know the Hungarian business life well will have little problem to find out the real names of the chosen firms. 
the possibility that his denial of internationalisation is actually the block to the company's export growth. The real reason why the company has turned away from exporting is increased competition, as most of the DIY products are available to anyone for very favourable prices, so "our product offering is simply not competitive enough for exporting."

Strategic expectations and unforeseen events both influenced succession planning in the company. "I consider planning very important, even for long term like 10 years, as succession is a long process." Meanwhile, an employee of the company is in charge of daily operations, our interviewee, the predecessor is now only involved in strategic decisions. Other than planning, an unfortunate event also caused this relative withdrawal from management. He suddenly became ill, hence his sons return from abroad and their gradual involvement in company operations. Originally, he planned his sons to take over the management of the company as a gradual process, but now the clear successor is understood to be the employee with significant local experience. Also, one of the sons has other interests and is unwilling to get involved in the management of the family firm.

\subsection{Sierra Limited}

Sierra Limited, one of the most famous family firms in Hungary, dates back its origins to the 1930's when the founder learned preparing marzipan from a Danish master. ${ }^{3}$ Due to the stormy conditions of $20^{\text {th }}$ century Hungary, the firm did not function during the early decades of socialism. The owner could re-start as a small entrepreneur only in 1971. However, 10 years later he had to withdraw from management due to a heart attack, so his son-in-law was appointed as the manager of the family business. Together with his wife, he was already involved in the company before by preparing specific tools and machinery for the company. While the couple is still active, today it is already the third generation in charge of the firm with the responsibility to implement the strategy. For the purposes of this article, we took the second generation as predecessors and the third generation as successors in focus, as there was little scope for internationalisation for the founder due to political and regulatory limitations. Our interviewee was the female member of the second generation, i.e. the daughter of the founder.

Today this family firm has over 20 shops, including one in Vienna (Austria), but external conditions restrained them from internationalisation in their early years. The real breakthrough was the change in the political system in 1989,

Marzipan is a confection consisting primarily of sugar or honey and almond meal (ground almonds), sometimes augmented with almond oil or extract. 
which opened new opportunities. "We have a track record of exporting for over 25 years now, and it all started by an Austrian businessman entering our shop." Foreign market entry was realised with the leadership of the predecessor, who was the decision maker at the time, with the support of his wife. With the help of the confectionary of the company in Budapest's high street, the firm gained international reputation not only in Austria, but also in Switzerland and Israel, among others. "A newspaper in Tel-Aviv wrote that there are three places where people are queuing in Budapest, that is McDonalds, Humanic and Sierra Limited." The family at that time felt the pressure for internationalisation as a burden, as foreign orders kept flowing in, they turned many of them down, hence the role of the Austrian partner, with his expertise, was critical in the firm's development.

Internationalisation, and in particular exporting has played an important role in the company from its early years. "This was how we could enlarge the production facilities (...) we had rose petal from marzipan (...) we used to sell five of them before, then we sold three tracks full of petals in one order, that is half a million of them at a time." Cooperation with international distributors helped the company after Hungary's EU-accession, when competition intensified. They do not stop thinking about innovations, despite strong exports. The third generation is currently working on setting an agreement with a major Austrian retail chain, as well as sending trial products to the United States of America. Nevertheless, the key export markets remain to be Austria and Germany.

The predecessor was also well prepared and keen to advance the firm's internationalisation. He speaks good English. He had structured plans to build the company's market internationally and started to make agreements with foreign distribution partners. He still supports the third generation of management with his advice regarding international operations. They have been involved in running the business from very early age. One of them was in charge of a shop, the other son was responsible for writing applications, before taking over the management of the company itself. The succession was well planned, the family made decisions together, though the father (predecessor) had the final word. Furthermore, the mother of the third generation lived in England for a while in order to support the language development of her sons that was meant to allow their future international business innovations. Besides, one of the sons has engineering diploma, just like his father, while the other has studied economics in order to take over the management of the family firm with good qualifications.

The third generation, however, wants more in terms of international operations. Our interviewee (mother of the third generation) admitted that they are underperforming in marketing, and her sons are willing to strengthen the corporate brand internationally. While the mother herself does not want to do more business abroad, the sons are clearly more ambitious. When asked about the reasons 
behind this difference in approach, she responded aptly: "for us it is our life, for them it is their business". Meanwhile, they are working on the renewal of the corporate structure to manage potential conflicts in a constructive way: the company was transformed into a holding with the father, one of his sons and an external manager being represented in the board. For strategic decisions, the support of the predecessors will still be required.

\subsection{Kilo Limited}

Kilo Limited was originally an individual entrepreneurship started over 30 years ago with a scope of trading second-hand goods. Today it is in control of the second generation of family management, as one of the tools traders of longest tradition in Szombathely (town in Western Hungary, close to the Austrian border). They employ over 20 colleagues and have a number of foreign partners. The company's activities have gradually increased in scope, ranging from the original tools trading to metal manufacturing, even by individual orders, and maintenance services. While the third generation is already employed by the firm, the ownership and management is in the hands of the three children of the company's founder. The oldest member of the management was our interviewee.

The founder's children started to get involved in the operations of the family firm while attending secondary school. While the company did not have a conscious strategy for long term, succession was planned, but not in details. However, the sudden illness of the founder necessitated his children to take control of the company, without any leadership experience. "Illness was the primary reason, hence the lack of time of him handing over the firm to us (...). I cannot imagine a better way of taking charge of a firm, however, as we were thrown in the middle of everything." He argued that the successor needs to make serious decisions in order to really feel what the responsibility of managing the company means, and this provides opportunities to learn. Luck may have also played a role, in his interpretation, as he studied economics for his planned career in banking, while his brother was studying engineering which proved equally useful when they took charge of the company.

A couple of years before the founder left the management of the firm, they started to work with foreign partners. "We did not rush these things but realised that in order to grow and improve our business we had to develop foreign distribution and supply partners." Both the founder and his children agreed on that, especially as the children did speak languages as well. All of these new partnerships started by utilizing existing friendships, and sometimes by taking advantage of unforeseen opportunities that came up. "It all started by very banal reasons 
in case of our Italian partner, as three ladies were in charge of their firm, they could not move heavy machinery and asked for our help (...) so we went there to help." A friend of the manager introduced them to the opportunity to work with Austrian partners, without much conscious planning. Regarding the future, the current management plans to introduce more consciousness in how they build international relationships, like attending industry trade fairs. Furthermore, they have recently engaged an advisor specialised in organizational development to work for them.

When asked about the potentially improving conditions of international trading, our interviewee confirmed the importance of trust in this segment. What can be a barrier to building new relationships is the extant experience of the potential partner. "One of our Austrian contacts, for example, had really bad experience from their previous case (...) they did not get the goods ordered, and even the down payment was lost." While the business is focused on technical goods of significant value, the issue of trust is fundamental in obtaining new trade partners. Management have realised that they need to arrange more conscious approach to export activities, as the issue of trust is even more challenging in online trading which "... is not a threat but an opportunity to take for us."

\subsection{Whiskey Limited}

Whiskey Limited has been involved in the trading of dental products since its establishment in 1996. Its owners are still the Whiskey family, more particularly the founding father and his daughter and son. The daughter was our interviewee, who used to be the $98 \%$ owner and top manager of the company, but now she has a more reserved role, mainly as an owner. The actual management is currently run by the new spouse of her father and their children.

The internationalisation of the firm followed an atypical pattern, unlike the usual gradual approach. They started the firm in response to an order from Czechia, and the daughter started the business with her parent's support. The parents spoke Slovakian, which facilitated the business development with the Czech partner. The daughter spoke English, which allowed her to get involved in the company's business rapidly. "I had to go to meetings early on, as the negotiation was in English. I prepared myself thoroughly so that I do not get confused with English... as the company provides the basis of living for the family, we have done all we could to grow the business."

Her father had a parallel other job, and her mother died suddenly, so the daughter started to lead the company on her own, without any previous planning of 
succession. Although her parents tried to involve her in the business beforehand, she had to quickly learn what management actually means. All the more, her father remained in ownership, but refused to get involved in the business after his wife's tragic death. "Of course, if I had wanted to do an utter blunder, he would have intervened, but that did not really happen." She thrived on the challenge of responsibility, and her father supported her ideas throughout.

Meanwhile, the Czech partner was taken over by a Swiss firm, and Whiskey Limited also received orders from Pakistan to distribute their products in Hungary. "There were times when it was very good business to import goods from Pakistan... this continued for long, but our clients started to make orders directly later." Import from Asia has lost its attraction, and though they sometimes received orders to distribute Chinese or Indian goods in Hungary, for favourable prices, but the quality of these products fall below expectations. Instead, they turned their attention to acquiring new partners in Europe. They participate in the trade fair in Cologne every year. "There we have found an Italian producer, whose products we really appreciate."

Now that the daughter has passed on the responsibility of management, the family members in charge have less appetite to develop new international partnerships. De-internationalisation of the firm's activities has gradually gained strength, though the re-internationalisation may happen later. The new generation of management is still learning themselves into running a company, one of them also learning dentistry, and they seem to be very motivated to set new strategic directions for the company. This, however, may materialise only in longer term, according to our interviewee.

\subsection{Golf Limited}

Golf Limited is a logistics services provider firm in Western Hungary. Their clients are mostly multinational firms and their geographical scope covers almost the entire continent. Golf Limited is a member of Golf Group, a diverse conglomerate of unrelated businesses. Golf Limited was established in 2002, but the current owners, the Golf brothers already worked with their father before he retired in 2003. He planned his retirement well in advance and involved his sons in the business for over 12 years. The third generation, his grandson is already working for the company, so the next round of succession is planned long before it will actually be completed.

One of the current owners (second generation) explained how he started the business, well before the current company was established: "I worked for the 
customs office for 10 years, after high school. Based on my robust knowledge of German language, I was well positioned to offer freight services to foreign clients who started to pay good fees after the political system changed in 1989." He was gradually involved in supporting his father, who also advocated internationalisation himself. While formally the father controlled the business, his sons were assigned jobs with responsibility early, particularly related to organising the freight. The company office is less than $30 \mathrm{~km}$ from the Austrian border; hence location was an advantage in providing logistics services to Western markets.

The predecessor and the successors differed in their approaches to internationalisation. The father targeted the neighbouring countries first, using a few vehicles only. His sons, however, were much more ambitious and keen to grow the business more rapidly, even though they had little or no experience abroad. Their expansion was quite successful, as they have 53 trucks today with 96 drivers, and connecting locations from Lisbon to Helsinki, across Europe. "It all went progressively... first we targeted the neighbouring countries, and then we ventured farther. Then came major clients LuK and Epcos, and an increasing number of companies, as we built our personal network of relationships. We reached even the farthermost parts of Europe."

With regards to the new opportunities and the presumably easier access to foreign markets following Hungary's admission to the European Union, the successor's response was: "everything is much easier, and everything is much more difficult". On the one hand, he appreciates the opportunities arising from joining the Union, and the operations of the global freight exchange which allows stakeholders access to immense measure of information. On the other hand, this opportunity is open for everyone, hence he is concerned about the growing complexity of the environment. Back in the times of his father, the predecessor, one could rely on trusted relationship with clients. As for now, freight agreements largely depend on financial models and paperwork.

For the future outlook of the company, our interviewee (the successor) sees himself as a conservative manager and would not himself set up a foreign subsidiary of the company. "This will be the task of the next generation of the family, with our full support." He wants his son to have higher education, speak languages, and learn into the daily operations of the business step by step. The next change of the generation in the family firm's management is expected to happen in 5-10 years, just like it was the case last time with him and his father. As a matter of fact, it remains open, whether the next generation of family leaders will bring the firms forward in its level of internationalisation, by setting up a foreign subsidiary. 


\subsection{Charlie Limited}

Charlie Limited is a relatively small company in our sample, dealing with the rental of industrial areas. It is currently owned by two families. Both the predecessor and the successor were available for personal, in-depth interviews.

Interestingly, the legal predecessor of the company used to have a foreign coowner, who sold its share in the company at a later stage. In 2003, when the two families took over the full ownership of the firm, they made an interesting decision regarding internationalisation: "Our company considered entering the Austrian market, it looked attractive, also from a taxation point of view. However, as the Austrian owner left the firm, we did not actively pursue internationalisation." The company is yet to enter the foreign market despite the fact that the father of one family speaks foreign languages and has experience in the international financial markets. Nevertheless, neither him, nor the other founder wanted to internationalise.

Both of the founders have died recently, and the successor does have international plans. He was raised consciously from an early age to learn how to run the family business. He was enrolled to business studies, and supports the company with advice, but has no formal position in the company yet. He believes both the financial background and the necessary experience exist for them to enter foreign markets, much more than what the case was in the early 2000's. "Internationalisation is my approach to the company's strategy, which is not yet agreed with the predecessors. (...) I trust that the accounting knowledge of my mother and the business analytical background of my brother could provide an advantage we would not want to lose." If necessary, he would start up a separate business with his family to support entering foreign markets. He cannot imagine losing this opportunity in the long term. While he did not emphasise it, he also has experience in international financial markets, just like his father had, who also taught him about this special field of expertise.

\section{DISCUSSION OF RESEARCH RESULTS}

\subsection{Proposition 1}

Regarding our first proposition, which claimed that the leadership style of the predecessor in the context of succession has a critical impact on the internationalisation of the family firm, the six examined cases show a diverse picture. In our analysis, no predecessor fit an exact type of leadership style, but they resembled certain types more than others. In three cases, succession was carefully planned 
with the predecessor playing a supportive role, nurturing the assigned successor gradually into the complete role of management. We have found that without exception, in all of these cases the successor plans further, more intensive internationalisation in the foreseeable future of the company. For Charlie Limited, the company is yet to enter the foreign market but the successor believes both the financial background and the necessary experience exists for them to enter foreign markets, and he could not imagine to lose this opportunity in the long term. For Golf Limited, the founders only entered the neighbouring countries, the successor reached the most remote parts of Europe with their services, and it is expected to be the task of the next generation of the family to bring the firm forward in its level of internationalisation, by setting up a foreign subsidiary.

By contrast, in the three other cases in our sample, succession was forced by external conditions (illness, death of the predecessor). The consequences are diverse, as in one case, the company still plans internationalisation to intensify under the management of the new generations, while in the other two cases, the companies de-internationalised. For Kilo Limited, the company started to work with foreign partners a couple of years before the sudden retirement of the predecessor. They agreed that the firm can only continue to grow if they set up new relationships abroad, both in terms of sales and supply. The new generation of management plans to introduce more consciousness in how they build international relationships, like attending industry trade fairs, and they have even engaged external organizational development specialists to help the process. In the case of Juliett Limited, the strategy of the predecessor who recently retired due to illness was de-internationalisation with expanded scope in the domestic market, as increased international competition rendered their offering less competitive. The third generation of management may change that later, but there are no signs for such an intention yet. For Whiskey Limited, the death of the predecessor put the successor quickly into a position of full responsibility, and she thrived in the international environment for a while, but then withdrew from management herself, and the third generation, without much preliminary preparation and qualifications, has less ambition to run business outside the borders of Hungary.

We understand from the company stories that there are strong contextual factors, like the sudden death or illness of the predecessor that dramatize the potential detrimental impact of lack of planned succession on the future of the company, most notably its internationalisation. When succession is planned and supported by the predecessor, we have found no cases where internationalisation would lose its strength. However, when succession was forced by external conditions, the lack of readiness by the new generation of family management could result in de-internationalisation. In the contemporary CEE context, internationalisation appears to be the standard, if not the only, strategic option for local family firms 
Table 2. The explored relationship between the leadership style of succession management by the predecessor and the internationalisation prospects of family firms

\begin{tabular}{|l|l|l|}
\hline Company code name & Leadership style of predecessor & Internationalisation prospects \\
\hline Charlie Limited & Supportive, carefully planned & Internationalisation will start \\
\hline Golf Limited & Supportive, carefully planned & Internationalisation will intensify \\
\hline Juliett Limited & $\begin{array}{l}\text { Succession forced by sudden } \\
\text { external conditions }\end{array}$ & De-internationalisation \\
\hline Kilo Limited & $\begin{array}{l}\text { Succession forced by sudden } \\
\text { external conditions }\end{array}$ & Internationalisation will intensify \\
\hline Sierra Limited & $\begin{array}{l}\text { Supportive, while remaining } \\
\text { available }\end{array}$ & Internationalisation will intensify \\
\hline Whiskey Limited & $\begin{array}{l}\text { Succession forced by sudden } \\
\text { external conditions }\end{array}$ & De-internationalisation \\
\hline
\end{tabular}

Source: Primary research by the authors.

to grow their business, but careful succession planning seems to be a necessary precondition for realising continuous internationalisation. While additional research is necessary to prove our refined proposition, the current investigation explored the importance of a supportive, conscious style of leadership by the predecessor in the context of succession for family firms' future sustainability in international markets.

\subsection{Proposition 2}

Regarding our second proposition which claimed that successor-led family firms are more open to internationalisation, the sample companies do not show an affirmative pattern, as illustrated by Table 3. Firstly, most of the predecessor-led companies were already quite open to internationalisation, even if they have not actually entered foreign markets. In the case of Charlie Limited, the founder

Table 3. Openness to internationalisation under the management of the predecessor and the successor

\begin{tabular}{|l|l|l|}
\hline Company code name & Under the predecessor & Under the successor \\
\hline Charlie Limited & Not in focus & Open \\
\hline Golf Limited & Open & Open \\
\hline Juliett Limited & Open & Not open \\
\hline Kilo Limited & Not in focus & Open \\
\hline Sierra Limited & Open & Open \\
\hline Whiskey Limited & Open & Not open \\
\hline
\end{tabular}

Source: Primary research by the authors. 
spoke languages and had experience in international markets, hence a level of internationalisation was probably present in his approach to business, even if he did not want to enter foreign markets. As for Kilo Limited, the predecessor already realised that internationalisation is needed for the sustainable growth of the company, he just could not take the company to an advanced level of internationalisation in the last couple of years under his management. Successors, however, started the internationalisation strategy with their father and are now willing to intensify the process under their management.

As a special note, it was part of our sampling criteria to select family firms to our sample that have significant international involvement. Whether this has been the case for a long time already or just recently was not relevant in sample selection. What we see in our research is that it is very rare for the founders not to think about immediate or at least medium-term internationalisation, this does not seem to be related to the change of generation in management. Openness to internationalisation, we may presume, is a contextual necessity in the region for family firms that pursue a sustainable growth strategy across generations. This may not always have been a conscious strategy, however. In the case of Juliett Limited, for example, the predecessor management did not intentionally reject internationalisation, they just did not give priority to such opportunities. Later on, in response to changes in the external environment the company started entering foreign markets as their multinational clients "took them abroad". In the case of Golf Limited, the nature of the industry, i.e. freight services raised the opportunity of international freight as soon as it was politically allowed. As for Whiskey Limited, the enterprise was actually started in response to an order from abroad. In the case of Sierra Limited, the sheer quality of the product offering attracted foreign clients visiting Hungary and saw the opportunity to help Sierra in sales abroad.

By contrast, some of the companies de-internationalised under the management of successors. As noted before, this can be explained by the fact that succession was not planned and the product of the company lost its competitiveness in the global market, potentially due to insufficient strategic initiative by the immature management under successors. In the case of Juliett Limited, the abrupt withdrawal of the predecessor from management may necessitate the involvement of professional management, but strategic decisions regarding the internationalisation of the company in the context of less competitive product on international markets probably needs support of the family owners of the firm, who are yet to support this option. As for Whiskey Limited, the third generation of management does not seem to be qualified and ambitious enough to maintain or improve the international involvement of the firm. Over time, they may decide to do so, but it is clearly a case of succession issue that created a situation where internationalisation lost its priority in the firm's strategy. 


\section{CONCLUSIONS AND FUTURE RESEARCH PERSPECTIVES}

The key conclusions from our research are that the supportive leadership style of succession management by the predecessor appears to have a strong impact on the internationalisation ambitions and success of family firms under the management of successors. A strong moderating factor may be the external environmental impact, most notably the abrupt health issues or death of the predecessor, which seems to make a detrimental impact on the future internationalisation of family firms, partly because of the lack of readiness and ability of the successors to manage the firm with an international growth strategy. Also, internationalisation appears to be a natural requirement for most of the family firms in Hungary, if they are willing to sustain their business across generations. De-internationalisation may be a defensive strategy to ensure the firm's survival for a period that allows the new generation of management to prepare the company for (re-) internationalisation.

All of the above conclusions, however need further examination to have robust validity and reliability for generalisation. The current results add to the emerging collective body of evidence on the business strategies of family firms. Our research connected the seminal issue of generational change with the fundamental strategic process of internationalisation. We added insights from a CEE region where succession is more of a challenge than in mature markets with longer traditions of uninterrupted family control or firms, and where internationalisation is a must for most firms, even if the cases of de-internationalisation are emerging.

The management implications of our findings are that proper succession planning may be vital for the sustainable success of the family business, and while deinternationalisation may be an option to sustain operations for an interim period, internationalisation cannot be removed from the strategic agenda of family firms in Hungary. The policy implications of our research drive attention to the crucial role of knowledge transfer across family firms in different historical regions, as examples from more mature markets can educate entrepreneurs in the CEE region about the priorities and issues in succession planning.

The limitations of our research are that there is little scope for generalisation of our results in their current form. The validity and reliability of our results could be further strengthened within the context of the current case studies with more interviews and analysing other sources of information to be collected. With regards to future research opportunities, we aim to extend our research to family firms with different approaches to internationalisation, following a wider range of business strategies. Also, the international comparative assessment of the impact of succession issues on the internationalisation of family firms can be justified as a timely and potentially insightful line of research for us in the future, including 
the application of both qualitative and quantitative methodologies. With more empirical information available at the future stages of our research, we plan to apply a more formal theoretical model which provides a framework for explanatory analysis with intention of generalisation, based on the initial findings of the current paper.

\section{REFERENCES}

Agarwal, R. - Kumar, A. - D’Souza, K. (2016): Issues in Career Choices of Successors in Family Businesses: Perspective from Literature Review. Journal of Applied Management and Investments, 5(1): 1-19.

Al-Dubai, A. A. S. - Ismail, K. I. N. K. - Amran, A. N. (2014): Family Business Definition: A Matter of Concern or a Matter of Convenience? Corporate Ownership \& Control, 11(2): 274-280.

Anderson, A. R. - Jack, S. L. - Dodd, S. D. (2005): The Role of Family Members in Entrepreneurial Networks: Beyond the Boundaries of the Family Firm. Family Business Review, 18(2): $135-154$.

Antalóczy, K. - Éltető, A. (2002): Magyar vállalatok nemzetköziesedése - indítékok, hatások, problémák. (The Internationalization of Hungarian Firms - Motives, Impact, Problems). Közgazdasági Szemle, 49(2): 158-172.

Antalóczy, K. - Sass, M. (2011): Kis- és közepes méretű vállalatok nemzetköziesedése - elmélet és empíria (Internationalization of Small to Medium Size Enterprises - Theory and Empirics). Külgazdaság, 40(9-10): 22-33.

Arregle, J. L. - Duran, P. - Hitt, M. A. - Van Essen, M. (2017): Why is Family Firms' Internationalization Unique? A Meta-Analysis. Entrepreneurship Theory and Practice, 41(5): 801-831.

Astrachan, J. H. - Klein, S. B. - Smyrnios, K. X. (2002): The F-PEC Scale of Family Influence: A Proposal for Solving the Family Business Definition Problem. Family Business Review, 15(1): $45-58$.

Astrachan, J. H. - Shanker, M. C. (2003): Family Businesses' Contribution to the US Economy: A Closer Look. Family Business Review, 16(1): 211-219.

Babbie, E. (2000): A társadalomtudományi kutatás gyakorlata (The Practice of Social Research). Budapest: Balassi Kiadó.

Bartha, Z. - S. Gubik, A. (2016): Az üzleti tudás hatása a visegrádi országok kis- és középvállalatainak nemzetköziesedésére (The Impact of Business Knowledge on the Internationalisation of Small to Medium Size Firms in the Visegrad Countries). Vezetéstudomány, 47(8): 15-25.

Bálint, A. (2006): Merre tovább középvállalkozások? - Stratégiai lehetőségek a vállalkozásátadás folyamatában (Where Next for Medium Size Firms? - Strategic Opportunities in the Process of Management Succession). PhD thesis, Corvinus University of Budapest.

Beamish, P. (1990): The Internationalisation Process for Smaller Ontario Firms: A Research Agenda. Research in Global Business Management, 1: 77-92.

Bhalla, V. - Kachaner, N. (2015): Succeeding with Succession Planning in Family Business. Available at: https://www.bcg.com/publications/2015/leadership_talent_growth_succeeding with_succession_planning_family_businesses.aspx Downloaded: 30 August 2018.

Boyd, B. - Royer, S. - Pei, R. - Zhang, X. (2015): Knowledge Transfer in Family Business Successions: Implications of Knowledge Types and Transaction Atmospheres. Journal of Family Business Management, 5(1): 17-37. 
Cano-Rubio, M. - Fuentes, G. - Vallejo, C. D. (2017): Influence of the Lack of a Standard Definition of "Family Business" on Research into their International Strategies. European Research on Management and Business Economics, 23(3): 132-146.

Cernat, L. - Norman-Lopez, A. - T-Figuearas, A. D. (2014): SMEs are More Important than You Think! - Challenges and Opportunities for EU Exporting SMEs. Available at: http://trade. ec.europa.eu/doclib/docs/2014/september/tradoc 152792.pdf Downloaded: 9 August 2018.

Cerrato, D. - Crosato, L. - Depperu, D. (2016): Archetypes of SME Internalization: A Configurational Approach. International Business Review, 25(1): 286-295.

Cesaroni, F. M. - Sentuti, A. (2017): Family Business Succession and External Advisors: The Relevance of 'Soft' Issues. Small Enterprise Research, 24(2): 167-188.

Chalus-Sauvannet, M. C. - Deschamps, B. - Cisneros, L. (2016): Unexpected Succession: When Children Return to Take over the Family Business. Journal of Small Business Management, 54(2): 714-731.

Chikán, A. - Czakó, E. (2014): Export és vállalati menedzsment (Export and Corporate Management). Available at: https://www.vg.hu/vallalatok/export-es-vallalati-menedzsment-433741/ Downloaded: 29 August 2018.

Chua, J. H. - Chrisman J. J. - Sharma, P. (1999): Defining the Family Business by Behavior. Entrepreneurship Theory and Practice, 23(4): 19-39.

Coviello, N. (2015): Re-thinking Research on Born Globals. Journal of International Business Studies, 46(1): 17-26.

Coviello, N. E. - Munro, H. J. (1995): Growing the Entrepreneurial Firm: Networking for International Market Development. European Journal of Marketing, 29(7): 49-61.

Coviello, N. - Munro, H. (1997): Network Relationships and the Internalisation Process of Small Software Firms. International Business Review, 6(4): 361-386.

Coviello, N. - Tanev, S. (2017): Initiating a New Research Phase in the Field of International Entrepreneurship: An Interview with Professor Nicole Coviello. Available at: https://timreview. ca/article/1077 Downloaded: 28 August 2018.

Cruz, C. - Nordqvist, M. (2012): Entrepreneurial Orientation in Family Firms: A Generational Perspective. In: Cesaroni, F. M. - Sentuti, A. (2017): Family Business Succession and External Advisors: The Relevance of 'Soft' Issues. Small Enterprise Research, 24(2): 167-188.

Czakó, E. (2005): Az EU hatása a vállalati versenyképességre - ahogyan a vállalatvezetők látják (The Impact of EU on Corporate Competitiveness - the View of Corporate Management). In: Tudásalapú társadalom. Tudásteremtés - Tudástranszfer. Értékváltás (Knowledge Based Society. Knowledge Creation - Knowledge Transfer, Value Change). $5^{\text {th }}$ International Conference, University of Miskolc, Faculty of Economics, pp. 51-55.

Csák Farkas, J. (2012): Családi vállalkozások - Fókuszban az utódlás (Family Firms - Succession in Focus). PhD thesis, Corvinus University of Budapest, Faculty of Business Administration.

Daszkiewicz, N. - Wach, K. (2014): Motives for Going International and Entry Modes of Family Firms in Poland. Journal of Intercultural Management, 6(2): 5-18.

De Massis, A. - Frattini, F. - Majocchi, A. - Piscitello, L. (2018): Family Firms in the Global Economy: Toward a Deeper Understanding of Internationalization Determinants, Processes, and Outcomes. Global Strategy Journal, 8(1): 3-21.

De Massis, A. - Kotlar, J. (2014): The Case Study Method in Family Business Research: Guidelines for Qualitative Scholarship. Journal of Family Business Strategy, 5(1): 15-29.

Devins, D. - Jones, B. (2016): Strategy for Succession in Family Owned Small Businesses as a Wicked Problem to be Tamed. Vezetéstudomány, 47(11): 4-15. 
Eddleston, K. A. - Kellermanns, F. W. - Floyd, S. W. - Crittenden, V. L. - Crittenden, W. L. (2013): Planning for Growth: Life Stage Differences in Family Firms. Entrepreneurship Theory and Practice, 37(5): 1177-1202.

Eigen, P (2007): "What You Still Need to Know"... The Generation Change in Family Firms and the Struggle for a Viable Truth. Corporate Advisory, Supervision, Coaching, 14(4): 392-403.

European Commission (2009): Final Report of the Expert Group. Overview of Family Business Relevant Issues: Research, Networks, Policy Measures and Existing Studies. Available at: http:/ec.europa.eu/enterprise/policies/sme/promoting-entrepreneurship/family-business/family business_expert group_report_en.pdf Downloaded: 18 April 2018.

Éltető, A. - Udvari, B. (2018): Nemzetköziesedés a válság után - a magyar kis- és középvállalatok exportjára ható tényezők (Internationalisation after the Crisis - Factors Affecting the Export of Hungarian Small to Medium Size Firms). Külgazdasági Szemle, 45(4): 402-425.

Family Firm Institute (2017): Global Data Points. Available at: https:/www.ffi.org/page/ globaldatapoints Dowloaded: 16 August 2018.

Fang, H. - Kotlar, J. - Memili, E. - Chrisman, J. J. - De Massis, A. (2018): The Pursuit of International Opportunities in Family Firms: Generational Differences and the Role of Knowledgebased Resources. Global Strategy Journal, 8(1): 136-157.

Fletcher, D. - De Massis, A. - Nordqvist, M. (2016): Qualitative Research Practices and Family Business Scholarship: A Review and Future Research Agenda. Journal of Family Business Strategy, 7(1): 8-25.

Goto, T. (2014): Family Business and Its Longevity. Kindai Management Review, 2: 78-96.

Graves, C. - Thomas, J. (2008): Determinants of the Internationalization Pathways of Family Firms: An Examination of Family Influence. Family Business Review, 21(2): 151-167.

Handler, W. C. (1989): Methodological Issues and Considerations in Studying Family Businesses. Family Business Review, 2(3): 257-276.

HVG (2016): A_családi_cégek_kétharmada_elvérzik_a_generációváltásban (Two Thirds of Family Firms Fail in Management Succession). Available at: http://hvg.hu/kkv/20160913_ Downloaded: 16 April 2018.

Incze, E. (2010): A multinacionálissá válás útjai Magyarországon - vállalatok nemzetköziesedésének idöbeni alakulása (The Ways of Intenationalisation in Hungary - the Temporal Process of the Internationalisation of Firms). PhD thesis, Corvinus University of Budapest, Institute of Management Science.

Johanson, J. - Mattsson, L. G. (1989): Strategic Action in Industrial Networks and the Development towards the „Single European Market”. Available at: https://www.escholar.manchester. ac.uk/api/datastream?publicationPid=uk-ac-man-scw:2n126\&datastreamId=FULL-TEXT.PDF Downloaded: 8 August 2018.

Johanson, J. - Vahlne, J. E. (2009): The Uppsala Internationalization Process Model Revisited: From Liability of Foreignness to Liability of Outsidership. Journal of International Business Studies, 40(9): 1411-1431.

Johanson, J. - Vahlne, J. E. (2017): The Internationalization Process 1977-2017: The Uppsala Model 40 Years Later. Journal of International Business Studies, 48(9): 1087-1102.

Kontinen, T. - Ojala, A. (2010a): The Internalization of Family Business: A Review of Extant Research. Journal of Family Business Strategy, 1(2): 132-146.

Kontinen, T. - Ojala, A. (2010b): Internationalization Pathways of Family SMEs: Psychic Distance as a Focal Point. Journal of Small Business and Enterprise Development, 17(3): 437-454.

Kontinen, T. - Ojala, A. (2012): Internationalization Pathways among Family-Owned SMEs. International Marketing Review, 29(5): 496-518. 
KSH (2010): Magyarország 1989 - 2009. A változások tükrében (Hungary 1989 - 2009. In the Light of Changes). Available at: https://www.ksh.hu/docs/hun/xftp/idoszaki/mo/mo1989_2009. pdf Downloaded: 29 August 2018.

KSH (2017): Mikrocenzus 2016. 4. Iskolázottsági adatok (Micro Census 2016. 4. Data of Education). Available at https://www.ksh.hu/docs/hun/xftp/idoszaki/mikrocenzus2016/ mikrocenzus 2016 4.pdf Downloaded: 29 August 2018.

KSH (2018): Gyorstájékoztató, külkereskedelmi termékforgalom (Quick Report. Foreign Trade) Available at http://www.ksh.hu/docs/hun/xftp/gyor/kue/kue1806.html Downloaded: 29 August 2018.

Michel, A. - Kammerlander, N. (2015): Trusted Advisors in a Family Business's Succession-Planning Process - An Agency Perspective. Journal of Family Business Strategy, 6(1): 45-57.

Mikesy, Á. (2013): A magyarországi mikro-, kis- és középvállalatok nemzetköziesedése és a külföldi értékesítést nehezítő akadályok. Egy vállalati felmérés tanulságai (The Internationalisation of Hungarian Micro, Small and Medium Firms and the Obstacles to Sales Abroad. Lessons from a Corporate Survey). Külgazdaság, 42(1-2): 92-120.

Miller, D. - Steier, L. - Breton-Miller, I. L. (2003): Lost in Time: Intergenerational Succession, Change, and Failure in Family Business. Journal of Business Venturing, 18(4): 513-531.

Noszkay, E: (2017): Tapasztalatok a családi vállalkozások átörökítésének dilemmái kapcsán (Experience Related to the Dilemmas of Succession in Family Firms). Vezetéstudomány, 48(6-7): 64-72.

Onkelinx, J. - Sleuwaegen, L. (2008): Internationalization of SMEs. Flanders DC and Vlerick Leuven Gent Management School, Gent.

Poza, E. J. (2007): Family Business. Mason, OH: South-Western Cengagae Learning.

Pukall, T. J. - Calabrò, A. (2014): The Internationalization of Family Firms: A Critical Review and Integrative Model. Family Business Review, 27(2): 103-125.

PWC (2011): Kin in the Game. Available at: https://www.pwc.com/gx/en/pwc-family-businesssurvey/assets/family-business-survey-2010-2011.pdf Downloaded: 18 April 2018.

Santangelo, G. D. - Meyer, K. E. (2017): Internalization as an Evolutionary Process. Journal of International Business Studies, 48(9): 1114-1130.

Sharma, P. (2004): An Overview of the Field of Family Business Studies: Current Status and Directions for the Future. Family Business Review, 17(1): 1-36.

Shi, X. H. - Graves, C. - Barbera, F. (2018): Intergenerational Succession and Internalisation Strategy of SMEs: Evidence from China. Available at: https://www.sciencedirect.com/science/ article/pii/S0024630117303886 Downloaded: 8 August 2018.

Sonnenfeld, J. (1988): The Hero's Farewell. In: Agarwal, R. - Kumar, A. - D’Souza, K. (2016): Issues in Career Choices of Successors in Family Businesses: Perspective from Literature Review. Journal of Applied Management and Investments, 5(1): 1-19.

Sorenson, R. L. (2000): The Contribution of Leadership Style and Practices to Family and Business Success. Family Business Review, 13(3): 183-200.

Stocker, M. (2017): De-Internationalisation Patterns in Hungary. Theory, Methodology, Practice. Club of Economics in Miskolc, 13(1):.109-118.

Stocker, M. (2019): Survival, Growth, and Performance of Hungarian International New Ventures. Society and Economy, 41(1): 47-64.

Stocker, M. - Czakó, E. (2018): Rejtett bajnokok és helyi hősök: az exportban sikeres vállalatok teljesítménye Közép-Európában és Magyarországon (Hidden Champions and Local Heroes: the Performance of Firms Successfully Exporting in Central Europe and Hungary). In: Tarjányi, M. - Vilmányi, M. (eds): Irányok trendek és tapasztalatok a stratégiai menedzsment kutatásában 
(Directions, Trends and Experiences in Strategic Management Research). Hungary: University of Szeged, Faculty of Economics, pp. 11-27.

Wang, C. (2010): Family Small Businesses: Definition, 'Essence' and 'True' Prevalence. International Journal of Entrepreneurial Venturing, 2(3-4): 276-290.

Yin, R. K. (1994): Case Study Research Designs and Methods. London: Sage Publications.

Zellweger, T. (2017): Managing the Family Business. Cheltenham: Edward Elgar Publishing,.

Ziniel, W. - Voithofer, P. (2016): Family Business Successions in Austria - Satisfaction and Incumbent-Successor Relationship. Vezetéstudomány, 47(11): 29-37.

Zou, S. - Stan, S. (1998): The Determinants of Export Performance: A Review of the Empirical Literature between 1987 and 1997. In: Cerrato, D. - Crosato, L. - Depperu, D. (2016): Archetypes of SME Internalization: A Configurational Approach. International Business Review, 25(1): 286-295.

Open Access. This is an open-access article distributed under the terms of the Creative Commons Attribution 4.0 International License (https://creativecommons.org/licenses/ by/4.0), which permits unrestricted use, distribution, and reproduction in any medium, provided the original author and source are credited, a link to the CC License is provided, and changes - if any - are indicated. (SID_1) 